\title{
Article
}

\section{Earthworms and mesofauna from an isolated, alkaline chemical waste site in Northwest England}

Butt, Kevin Richard and Briones, M

Available at http://clok.uclan.ac.uk/16475/

Butt, Kevin Richard ORCID: 0000-0003-0886-7795 and Briones, M (2017) Earthworms and mesofauna from an isolated, alkaline chemical waste site in Northwest England. European Journal of Soil Biology, 78 (Jan/Fe). pp. 43-49. ISSN 1164-5563

It is advisable to refer to the publisher's version if you intend to cite from the work. http://dx.doi.org/10.1016/j.ejsobi.2016.11.005

For more information about UCLan's research in this area go to http://www.uclan.ac.uk/researchgroups/ and search for <name of research Group>.

For information about Research generally at UCLan please go to http://www.uclan.ac.uk/research/

All outputs in CLoK are protected by Intellectual Property Rights law, including Copyright law. Copyright, IPR and Moral Rights for the works on this site are retained by the individual authors and/or other copyright owners. Terms and conditions for use of this material are defined in the policies page.

\section{CLoK}

Central Lancashire online Knowledge www.clok.uclan.ac.uk

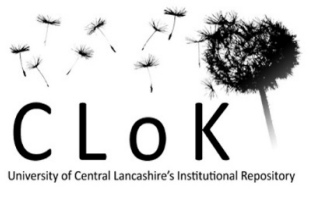


Earthworms and mesofauna from an isolated, alkaline chemical waste site in Northwest England

Kevin R. Butt ${ }^{1,2 *}$ and Maria J. I. Briones ${ }^{3,4}$

1. School of Forensic and Applied Sciences, University of Central Lancashire, Preston, PR1 2HE, UK

2. North-West University, Potchefstroom, South Africa, 2520

3. Dept Ecología y Biología Animal, Facultad de Biología, Universidad de Vigo, 36310 Vigo, SPAIN

4. CEH Lancaster, Library Avenue, Bailrigg, Lancaster LA11 4AP, UK

*Corresponding author: krbutt@uclan.ac.uk 


\begin{abstract}
Post-industrial sites across Europe may have developed over periods in excess of a century, often leading to poor nutrient soils with noxious constituents and extreme $\mathrm{pH}$ values. One such site, Nob End (Bolton, UK), a toxic tip created in the 1800s from a sodium carbonate factory, represents an "island of alkalinity in an acidic sea" where the weathering process (from $\mathrm{pH}$ 12) has provided a suitable environment for a rich alkali-loving flora and hence, deserving its designation as a Site of Special Scientific Interest. Despite their importance, the belowground communities have not been investigated and for this reason, in this study, we explored how soil macro- and mesofauna communities respond to extreme $\mathrm{pH}$ values in a system that has also experienced recent changes in management practices. As expected, earthworms, mites, insects and woodlice numbers were significantly higher and the community diversity enriched at the $(\mathrm{now} \mathrm{pH} 8)$ alkaline sites, whereas in areas where acidic boiler waste was historically deposited, enchytraeids, collembolans and dipteran larvae populations dominated the soil communities. Surprisingly, site management (cutting back of scrub) in the alkaline soil areas had a significant positive effect on soil macro-fauna by promoting numbers and biomass, but severely reduced the microarthropod populations. A transect investigation across an increasing pH gradient (from 4.5 to 8.0) was mirrored by a rise in earthworm numbers and species richness. Earthworms were further investigated surrounding the site, seeking potential sources of colonisation, with the majority of species at Nob End also present in adjacent non-industrially-influenced areas. This work demonstrates that soil fauna can ultimately colonise extreme edaphic conditions and these extreme environments have not prompted the development of specific faunal communities. As management of above-ground communities significantly influenced soil invertebrate communities, this could represent an important restoration practice to improve soil structure and fertility at this polluted site.
\end{abstract}

Keywords: Earthworm, Edaphic conditions, Leblanc process, Mesofauna, Soil development 
Highlights:

- Greater biological activity in these alkaline residues indicate they can be rehabilitated.

- Scrub management can increase macrofauna activities.

- Earthworm colonisers likely derived from adjacent areas unaffected by industrial history.

- Larger fauna show less tolerance to soil acidity than smaller invertebrates. 


\section{Introduction}

The northwest of England has an historic connection to industrial processes resulting in industrial wastelands with heavily contaminated soils. Many of these areas were despoiled during the working life of the given industry, with a large number of derelict sites now rehabilitated to some degree $[1,2]$. However, some sites were not reclaimed, but following ecological survey were deliberately left relatively untouched as they proved to be floristically rich and offered distinct edaphic conditions compared with more natural surrounding soils. During the nineteenth century, at Nob End (near Bolton, UK), Leblanc waste from the chemical synthesis of sodium carbonate (washing soda) was often dumped close to the production site to depths of $10 \mathrm{~m}$ or more. This process was in operation at a number of sites in the northwest of England to service the local cotton industry [3]. However, this site is now the only one that remains in England, and has been designated a Site of Special Scientific Interest (SSSI) for its nationally rare plant species, including a rich variant of a tall fescuecoltsfoot community and several species of orchids, [4,5]. Little attention, however, has been paid to invertebrates, except for unpublished investigations of molluscs [6] and brief mention of Lepidoptera by Shaw and Halton [7], with no known records of soil-specific fauna. In addition, Richardson [8] suggests that grassland sites derived from urban developments, with e.g. soils of extreme $\mathrm{pH}$, cannot be defined using botanical criteria alone and that survey of invertebrates is required for any selection as priority habitat for conservation. So, investigations of soil fauna were undertaken, focusing specifically at ecosystem engineering groups $[9,10]$ that might have direct actions on soil development through provision of ecosystem services [11].

The aim of this work was therefore to document soil fauna in the grass-covered, weathered Leblanc waste at Nob End. Specific objectives were: (i) to describe earthworm and mesofauna communities at areas of varying $\mathrm{pH}$ values; (ii) to link invertebrate community composition and structure to known site history and current management practices; (iii) to seek potential areas that could represent the most likely pool for earthworm colonisers of this heavily contaminated soil.

\subsection{Materials and Methods}

\subsection{Study site}

Nob End, Farnworth, is located $4.5 \mathrm{~km}$ from Bolton, within Moses Gate Country Park (53 $33^{\prime}$ $08^{\prime \prime} \mathrm{N}, 02^{\circ} 22^{\prime} 47^{\prime \prime} \mathrm{W}$ ) and owned and managed by Bolton Metropolitan Borough Council. This 8.8 ha site, lying at the confluence of the Rivers Croal and Irwell, consists of a plateau with 20 $\mathrm{m}$ high steep sides [5], has been extensively surveyed floristically for its orchid-rich flora $[7,12]$.

On site, the soil-forming substrate (wastes from the Leblanc process), known locally as "galligu", was originally caustic when dumped, with a pH of 12 and largely consisted of calcium sulphide mixed with calcium oxide and unburned coal. Deposition of the waste material continued for a period of around 50 years until the 1880s, after which the site was abandoned due to its extremely noxious nature.

Over the intervening years, weathering from the surface has occurred to provide a novel substrate in this locality. The uppermost organic-rich horizon of the soil extends to a depth of $5-10 \mathrm{~cm}$. Below this, there is an orange-coloured mineral soil developed from the weathered Leblanc waste, extending to a depth of $1 \mathrm{~m}$ in places. The orange colour of the sub-surface horizon is derived from iron impurities of unknown origin [7]. Deeper down, un-weathered grey/blue galligu is present - this colour derived from reduced iron compounds.

\subsection{Soil fauna communities in selected areas under contrasting vegetation and different management}

Three areas were selected for sampling (Fig. 1) based on relevant material available $[5,7,13]$ and consultation with the Site Manager from Bolton Council, with respect to historical events and specifically more recent management:

UNMAN: An unmanaged base-rich area where scrub (Hawthorn - Crataegus monogyna - in particular) had encroached over the open calcareous vegetation. Ground flora was diverse, herb-rich with a reduced grass presence. Examples included carline thistle (Carlina vulgaris), purging flax (Linum catharticum) and common centaury (Centaurium erythraea).

MAN: A managed base-rich area that had a similar flora to the unmanaged area, except that scrub had been cut back and removed (since the 1990s) to leave more open grassland. 
Some herbicides had also been applied here, and work between 2004 and 2007 involved applying Tricloyr, diluted with diesel, directly to cut hawthorn stumps by paint brush and one area of bramble (Rubus fruticosus) (of approx. $10 \mathrm{~m}^{2}$ ) was weed-wiped in 2005 using glyphosate [14].

CAL: A Calluna-rich grassland area where boiler waste was historically dumped above the alkaline Leblanc waste $[4,7]$ and resulting acid soils provided conditions where ling heather (Calluna vulgaris) is able to grow. Other typical vegetation here is mat-grass (Nardus stricta) and wavy hair-grass (Deschampsia flexuosa) - National Vegetation Classification - U2a [15]. In some of the acidic areas, no vegetation is present above a grey, granular substrate. In October 2008, at each of the 3 locations (Fig. 1) soil samples were collected from any distinct horizons, organic $(0-10 \mathrm{~cm})$ and mineral $(10-20 \mathrm{~cm})$. Samples from the upper horizons were analysed [16] in the laboratory for moisture content, organic matter content (loss on ignition) and $\mathrm{pH}$. Samples of the orange-coloured mineral material (in the alkaline sites) had $\mathrm{pH}$ determined.

Earthworms were collected by a combination of hand-sorting and chemical expulsion from an area of $0.1 \mathrm{~m}^{2}$, delineated by a quadrat. Firstly the soil was dug out to $0.2 \mathrm{~m}$ and the material was hand-sorted for earthworms and thereafter, five litres of a mustard vermifuge $\left(5 \mathrm{~g} \mathrm{~L}^{-1}\right)$ were poured into the resulting hole and monitored for emerging earthworms [17]. Five replicates were sampled at each location to minimise damage to the area. In the laboratory, collected earthworms, preserved in $0.4 \%$ formaldehyde, were identified to species, following the nomenclature of Sims and Gerard [18], and had biomass determined.

Soil samples for mesofaunal extractions were collected using an auger (diameter $10.5 \mathrm{~cm}$ ) to a depth of $0.15 \mathrm{~m}$. These were extracted from the corer and carefully sealed in plastic bags to prevent any chance of escape and kept intact for mesofauna extraction $(n=10$ replicates per location). Each sample was divided into two and each half used to extract either enchytraeids and dipteran larvae using a modified wet funnel method [19] or microarthropods (i.e. mites, collembolans, millipedes, spiders, etc.) using Tullgren [20] extraction. The extracted animals were allocated to groups using a stereoscopic microscope and reported as total numbers $\mathrm{m}^{-2}$.

\subsection{Change in soil community composition along a $\mathrm{pH}$ gradient}

Further sampling for earthworms was undertaken in September 2009 along a line transect laid between the two "unmanaged" areas representing two extreme $\mathrm{pH}$ values, i.e. the Calluna-rich (CAL) and the scrub-rich area (UNMAN) from the previous year (see Fig. 1). Earthworm samples ( $n=3$, as in section 2.2) were collected every 10 m over a distance of 110 $\mathrm{m}$. This line transect was across a grass-dominated area, but intercepted a patch of bramble and some hawthorn scrub. It traversed an area that was historically the location of the Prestolee Alkali Works [13], where the ground was broken and contained elements of rubble.

\subsection{Earthworms from surrounding unaffected habitats}

Additional soil sampling for earthworms was performed at positions labelled 1-5 on Fig. 1 in October 2009. These were located across the "necks of land" that attach Nob End directly to the surrounding countryside, as the River Croal to the west, the River Irwell to the SE and the disused Manchester, Bury and Bolton Canal to the north make this site a near-island. Site 1 was a sycamore (Acer pseudoplatanus)-dominated woodland, with areas of dressed stone providing evidence of past industrial use; site 2 was immediately beside the River Irwell with some willow (Salix spp.) present; site 3 was within path-side mown grass, adjacent to the canal; 4 was in hawthorn and elder (Sambucus nigra) woodland adjacent to a weir on the River Croal; and 5 was path-side, close to a stand of invasive Japanese Knotweed (Fallopia japonica).

\subsection{Statistical Analyses}

Soil fauna abundances were expressed as density (numbers per square metre). Diversity indices (Shannon-Wiener and Simpson) were calculated to characterise the given communities. One way ANOVA was used to determine the significant effects of dominant vegetation/management on the structure of soil communities.

\section{Results}

\subsection{Soils at Nob End}


Measurements of $\mathrm{pH}$ for MAN, UNMAN and CAL revealed that recent management practices have reduced the soil pH (Table 1). Loss on ignition results for the 3 sites were variable but all replicates from the site fell between 17.5 and $20.8 \%$ and all three soils were fairly dry (Table 1).

\subsection{Effects of vegetation type and management on abundance and diversity of soil organisms} 3.2.1. Oligochaetes (Annelida, Oligochaeta): Families Enchytraeidae and Lumbricidae Total Enchytraeid numbers were significantly affected by the treatments, with up to five and eight times more enchytraeids present in CAL than in the UNMAN or MAN systems, respectively (Fig. 2a).

No earthworms were extracted using a mustard vermifuge and hence, all individuals collected were living in the upper organic rich soil layer. Seven earthworm species were identified (Table 2) belonging to three ecological groupings: 2 litter dwelling (epigeic) species, Lumbricus castaneus and Lumbricus rubellus; 2 deep burrowing (anecic) species, Aporrectodea longa and Lumbricus terrestris) and 3 mineral working (endogeic) species, Aporrectodea caliginosa, Aporrectodea rosea and Octolasion cyaneum. The MAN area had the greatest species richness, but like UNMAN, the community was dominated by endogeic earthworms. By contrast, CAL had only 3 species, with $L$. rubellus being the most prevalent, representing $88 \%$ of the total.

Earthworm numbers and biomasses were also significantly different $(p<0.05)$ across the 3 sampled areas, with the MAN area supporting higher values than UNMAN and these more than CAL (i.e. 204, 134, and $64 \mathrm{~m}^{-2}$ and 78, 40 and $18 \mathrm{~g} \mathrm{~m}^{-2}$, respectively).

Additional immature earthworm specimens were also collected from mesofaunal extraction. These included one individual of $A$. caliginosa, one O. cyaneum and three Dendrobaena octaedra from UNMAN; one immature $A$. rosea, $A$. caliginosa and Lumbricus sp. from MAN and 2 immature Lumbricus spp. in CAL. As D. octaedra was not collected from standard earthworm sampling, it provided a total of eight earthworm species from the three selected areas at Nob End.

\subsubsection{Microarthropods (Arthropoda): Subphyla Chelicerata, Myriapoda, Crustacea and Hexapoda}

In overall abundance, the arthropods were the largest and most diverse group of the soil invertebrate community, with up to 67 families identified - belonging to 19 orders and included in 4 subphyla (see supplementary data). Average total numbers showed that UNMAN contained higher abundances (more than 150,000 individuals $\mathrm{m}^{-2}$ ) than the other two areas sampled although the differences were not significant (Fig. 2b).

The microarthropod community was clearly dominated by Acari (mites) and Insecta (collembolans, Protura, Diplura plus pterygota insects). Crustaceans (Isopods) were absent from the acidic site and, overall, fewer individuals of all subphyla were recorded compared with the two alkaline sites (Table 3 ). The only exceptions were mites and collembolans (Table 4): in particular the great abundance of springtails and Trombidiformes mites. Two families of oribatid mites (Carabodidae and Nanhermaniidae) were exclusive to the acid site, although with scarce presences. In contrast, Neelipleona, Symphyla, five families of oribatids (Brachychthonniidae, Ctenobelbidae, Galumnidae, Gehypochtoniidae and Ptiracaridae) and two of Prostigmata mites (Tetranychidae and Trombididae) were only present at the two alkaline sites. Finally, the soil under CAL contained the highest density of Dipteran (fly) larvae (Fig 2c). These were geophilous forms that spend only part of their lives in the soil. Diversity and evenness indices (Shannon-Wienner and Simpson) showed that treatment did not affect the Simpson index, but significant differences were observed in the ShannonWienner index and evenness (Figure 3). The fact that the Simpson Index gives more weight to the more abundant species in a sample means that addition of rare species to a sample causes only small changes in the value of $D$. In contrast, the Shannon index accounts for both abundance and evenness of the species present. Our results indicated that the microarthropod diversity at the two area with alkaline wastes were much higher than at the acidic area; however, the individuals in the CAL community were distributed more equitably among these families. Indeed the Calluna-dominated area contained 14 and 8 fewer families than the unmanaged and managed areas, respectively Management clearly reduced Chelicerata abundances by nearly half (46\%). In particular, Sarcorptiformes mites were very sensitive to management and reductions of around $55 \%$ were observed (Table 4). This was mainly due to an important (73\%) decrease in Oribatid 
mite abundance. Furthermore, four oribatid families (Ceratozetoidea, Camisiidae, Scheloribatidae and Thrysomidae), which were also present in the acidic area, disappeared as a result of management together with two exclusive families of the unmanaged area (Euzetidae and Haplozetidae). By contrast, the managed area favoured all collembolan groups (with the exception of Symphypleona), the numbers and diversity of Myriapoda and Endeostigmata mites, but a reduction in the average numbers of insects (with the exception of Hymenoptera and Tisanoptera) (see supplementary material).

\subsection{Effect of soil $\mathrm{pH}$ on earthworm community structure}

Figure 4 shows the change in $\mathrm{pH}$ across the site from CAL to UNMAN with corresponding earthworm community densities. A rising level of $\mathrm{pH}(4.45$ to 8.0$)$ from $0-70 \mathrm{~m}$ along the line transect, was mirrored by a general rise in earthworm density (Table 5). As pH values levelled at $70 \mathrm{~m}$, a fall in earthworm numbers was recorded. This fall was associated with deteriorating soil conditions, heavily influenced by previous constructions as sample areas had soils containing brick fragments and other rubble (see Figure 4 and Table 5).

Three previously unrecorded earthworm species from Nob End were found across the line transect. Dendrodrilus rubidus was located at the acidic CAL area $(0 \mathrm{~m})$; Allolobophora chlorotica (green morph) was continuously present from $10 \mathrm{~m}$ to $50 \mathrm{~m}$ and Aporrectodea icterica was represented by a single mature specimen at $60 \mathrm{~m}$. No earthworms were expelled with a vermifuge.

\subsection{Potential earthworm colonisation routes}

Results from areas adjacent to Nob End revealed a total of nine earthworm species in the mainly alkaline soils, a sub-set (minus $A$. icterica and $D$. rubidus) of the 11 in total recorded from the Nob End site (Table 5 and 6). Very few earthworms $\left(13 \mathrm{~m}^{-2}\right)$ were present close to the river (site 2) with the highest density $\left(330 \mathrm{~m}^{-2}\right)$ present in canal-side grassland (site 3). The only acidic soil ( $\mathrm{pH} 4.67$ ) was below Japanese Knotweed, where earthworm density was $97 \mathrm{~m}^{-2}$. L. terrestris was extracted with a mustard vermifuge at the woodland site (No. 4), where good quality brown earth soil was present.

\section{Discussion}

Sampling for soil invertebrates at Nob End revealed a relatively diverse fauna. From the extremely alkaline waste product dumped there over a century and a half ago, a shallow soil has developed. The survey work confirmed that macrofauna (earthworms) have colonised this soil, but they are restricted to the upper organic-rich horizon. Since none were found to enter the orange horizon at 5-10 $\mathrm{cm}$, this has important implications for the activities of deep burrowing species such as $L$. terrestris (found on site in some non-acidic areas), as these normally occupy a burrow to a depth of $1 \mathrm{~m}$ or more [21].

The soils at Nob End do not fall into standard soil classifications, due to their origins. The review by Bullock and Gregory [22] indicated that urban (anthropogenic) soils may need to be viewed individually and their management assessed carefully depending on site objectives. Soil development may take decades to centuries, as discussed by Bradshaw [23,24], where considerations of physical and biological processes involved in natural ecosystem development on degraded land are vital, but here the chemical changes required in the very alkaline waste must have initially outweighed all of these. In addition, presence of acidic boiler waste on site (in places still un-vegetated) means Nob End remains a site of particular interest with a diversity of soil-forming materials in close proximity.

Indeed, the earthworm species composition located below the acidic grassland (CAL), where soil $\mathrm{pH}$ was below 5 , confirmed the presence of an acidophilic epigeic grouping dominated by $L$. rubellus with $L$. castaneus, $D$. octaedra and $D$. rubidus. These species were classified by Satchell [25] as either acid-tolerant (the two latter) or "ubiquitous". In the more alkaline soils, whether scrub-managed or unmanaged, greater species richness was recorded with all ecological earthworm groups present, but even here earthworm densities (134-230 $\mathrm{m}^{-1}$ during 2008 and 2009) were dramatically lower than records for more naturally developed British grasslands (reviewed by Edwards and Bohlen [26]). Nevertheless, in the more alkaline areas, species composition, included $A$. chlorotica, $A$. caliginosa and $A$. longa, those deemed acidintolerant by Satchell [25].

The hawthorn clearance undertaken to maintain the floristic diversity of the site also appeared to affect soil organisms to an extent that might not have been expected, with positive effects on earthworm numbers, biomass and diversity observed compared with unmanaged areas, 
despite a much lower soil $\mathrm{pH}$ value (Table 1). Madritch and Lindroth [27] reported that removal of invasive buckthorn (Rhamnus cathartica) had a deleterious effect on exotic lumbricid numbers (over a 3 year period) in hardwood forests in the USA. This was attributed to interruption of feedback loops associated with good quality leaf litter provision. At Nob End, although a totally different system, the reverse was recorded. This could be a function of the diverse alkaline-loving flora present on site thriving in the absence of hawthorn and themselves providing a range of higher quality litter for potential earthworm consumption. The presence of rabbits on site, depositing faeces in more open areas could also be a relevant factor, as concentration of dung, with associated nutrients [28] may lead to greater soil fertility and hence greater earthworm density. Differences recorded may be worthy of further direct investigation with respect to soil nutrients.

Assessment of mesofaunal densities revealed an inverse relationship between earthworm and enchytraeid numbers as a result of $\mathrm{pH}$ changes. This however, is not unusual as enchytraeids are acidophilic and occupy soils where earthworms tend to be absent or only present in low numbers [26]. Furthermore, it has been observed that earthworm activities can eliminate enchytraeids from the organic top soil [29]. Among the attributed causal factors are competition for food resources, abiotic factors and changes in microbial communities as a result of $\mathrm{pH}$ changes [30].

In addition, with the exception of collembolans and a few Acari orders, the majority of the microarthropod groups were more abundant in the alkaline sites. This contrasts with previous observations in tropical soils [31], where arthropods were found to be more tolerant to acidic conditions, and can be explained by the greater abundance of ants and termites in tropical soils which have been found to be associated with lower $\mathrm{pH}$ [32].

The transect investigation provided a straightforward comparison of the changes in earthworm community composition from the acid to alkaline condition. The $\mathrm{pH}$ values did show a gradation with associated changes in species composition and earthworm community density (Fig. 4) but this was slightly confounded by anthropogenic influences on soil conditions at the site of the Prestolee Works [13] where brick rubble and glass often comprised a large proportion of the soil sampled. Nevertheless, this transect did reveal additional earthworm species on site. Site creation and deposition of at least 2 types of waste materials with extremes of $\mathrm{pH}$ [7] with the addition of further demolition waste unfortunately mean clear resolution of direct soil influences are difficult to discern.

Nevertheless, once soils had developed sufficiently for vegetation colonisation, as recorded from the 1950s [15] but probably much earlier, colonisation by earthworms from adjacent habitats would have been possible. These surrounding habitats confirmed all species present at potential colonisation sites are now present at Nob End. The size of Nob End and recorded rates of earthworm colonisation, as indicated by Eijsackers [33] and references therein, mean that once acceptable soils were developed, even if quite shallow, they could have been inhabited by earthworms relatively rapidly. This is something that has been recorded on soils derived from bauxite residues with similar $\mathrm{pH}$ values, where $A$. rosea and $L$. rubellus were present after 1 to 12 years [34]. Given the current paucity of data from soils derived from extremely alkaline waste materials, the findings provided here indicate that even in nutrient impoverished soils, with extremely high $\mathrm{pH}$ values and potential toxic concentrations of carbonates, aluminium and iron, soil organisms can eventually thrive. Work on similar soils with $\mathrm{pH}$ of around 8, derived from bauxite residues [35], have shown that macroarthropods will also colonise in less than a decade, with assisted revegetation.

Further investigations of soil fauna at the site under investigation here will undoubtedly reveal a greater insight into the relationships of their composition and edaphic conditions and the time scale of soil development, which could provide valuable information for restoration policies. As suggested by Shaw and Halton [7] Nob End would provide an ideal opportunity to re-expose some of the un-weathered $(\mathrm{pH} \mathrm{12)}$ material and then monitor its transformation, but this might meet with local and health-related opposition. However, it would provide a unique chance to record colonisation by both plants and soil invertebrates over timescales measured in decades.

\section{References}

[1] R.P. Gemmell, Colonisation of Industrial Wasteland - The Institute of Biology's Studies in Biology No. 80, Edward Arnold, London, 1977. 
[2] A.D. Bradshaw, M.J. Chadwick, The Restoration of Land, Blackwell Scientific Publications, Oxford, 1980.

[3] Cottontown (Undated) The cotton industry in the NW of England.

Available at http://www.cottontown.org/ Blackburn and Darwen, a community history, undated (accessed 18/02/16).

[4] R.P. Gemmell, S.A. Crombie, Management of waste tips for enhancement of landscape quality, Land. Res. 1 (11) (1975) 10-11.

[5] English Nature, SSSI notification for Nob End. http://www.english-nature.org.uk/citation/citation photo/1003648.pdf (accessed 02/02/13).

[6] S.J. Ryan, The terrestrial mollusc community at Nob End, Little Lever, Bolton a SSSI site with reference to four habitat types, Unpublished MSc thesis (Lancaster University), 2007.

[7] P. Shaw, W. Halton, Classic Sites: Nob End, Bolton, British Wildlife 10 (1998) 13-17.

[8] D. Richardson, Grasslands Habitat Action Plan. Greater Manchester Biodiversity Project. http://www.gmbp.org.uk/site/images/stories/grasslands\%20bap 09.pdf , 2009 (accessed 03/04/15).

[9] C.G. Jones, J.H. Lawton, M. Shachak, Organisms as ecosystem engineers, Oikos 69 (1994) 373-386.

[10] P. Jouquet, J. Dauber, J. Lagerlof, P. Lavelle, M. Lepage, Soil invertebrates as ecosystem engineers: Intended and accidental effects on soil and feedback loops, Appl. Soil Ecol. 32 (2006) 153-164.

[11] M. Blouin, M.E. Hodson, E. Aranda Delgado, G. Baker, L. Brussaard, K.R. Butt, J. Dai, L. Dendooven, G. Pérès, J. Tondoh, J. Cluzeau, J-J. Brun, A review of earthworm impact on soil function and ecosystem services, Eur. J. Soil Sci. 64 (2013) 161-182.

[12] H.J. Ash, R.P. Gemmell, A.D. Bradshaw, The introduction of native plant species on industrial waste heaps: a test of immigration and other factors affecting primary succession, $\mathrm{J}$. Appl. Ecol. 31 (1994) 74-84.

[13] P. Sharples, Nob End: History, Management and Development, Unpublished.

[14] P. Sharples, Management of hawthorn at Nob End SSSI: personal communication, (email of 11/03/09).

[15] J.S. Rodwell, (Ed.), British Plant Communities Vol. 3 - Grasslands and Montane Communities, Cambridge University Press, Cambridge, 1992.

[16] M.A.F.F., The analysis of agricultural materials - A manual of the analytical methods used by the Agricultural Development and Advisory Service, second ed., H.M.S.O., London, 1981.

[17] K.R. Butt, N. Grigoropoulou, Basic Research Tools for Earthworm Ecology, Applied and Environmental Soil Science, vol. 2010, Article ID 562816, 12 pages, 2010, doi:10.1155/2010/562816. http://www.hindawi.com/journals/aess/2010/562816.html (accessed 02/09/11).

[18] R.W. Sims, B.M. Gerard, Earthworms - Synopses of the British fauna No. 31 (revised), The Linnean Society and the Brackish-Water Sciences Association. Field Studies Council, Shrewsbury, 1999. 
[19] F.B. O'Connor, Extraction of enchytraeid worms from a coniferous forest soil, Nature 175, (1955) 815-816.

[20] A. Tüllgren, Ein sehr einfacher Ausleseapparat für terricole Tierformen, Zeischrift für Angewandte Entomologie 4 (1918) 149-150.

[21] M.J. Shipitalo, K.R. Butt, Occupancy and geometrical properties of Lumbricus terrestris L. burrows affecting infiltration, Pedobiol. 43 (1999) 782-794.

[22] P. Bullock, P.J. Gregory, Soils in the Urban Environment, Blackwell Scientific Publications, Oxford, 1990.

[23] A.D. Bradshaw, The reconstruction of ecosystems, J. Appl. Ecol. 20 (1983) 1-17.

[24] A.D. Bradshaw, The importance of soil ecology in restoration science, in K.M. Urbanska, N.R. Webb, P.J. Edwards (Eds.), Restoration ecology and sustainable development, Cambridge University Press, Cambridge, 1997, pp. 33-64.

[25] J.E. Satchell, Some aspects of earthworm ecology, in: D.K.Mc.E. Kevan (Ed.), Soil Zoology, Butterworths, London, 1955, pp.180-201.

[26] C.A. Edwards, P.J. Bohlen, Biology and Ecology of Earthworms, third ed., Chapman and Hall, London, 1996.

[27] M.D. Madritch, R.L. Lindroth, Removal of invasive shrubs reduces exotic earthworm populations, Biol. Inv. 11 (2009) 663-171.

[28] S.J. Willott, A.J. Miller, L.D. Incoll, S.G. Compton, The contribution of rabbits (Orictolagus cuniculus L.) to soil fertility in semi-arid Spain, Biol. Fertil. Soils 31 (2000) 379-384.

[29] M. Räty, V. Huhta, V, Earthworms and pH affect communities of nematodes and enchytraeids in forest soil, Biol. Fertil. Soils 38 (2003) 52-58.

[30] A. Beylich, U. Graefe, Relationships between microannelid and earthworm activity, Landbauforschungv TIAgric. For. Res. 357 (2012) S1-12.

[31] P. Lavelle, A. Chauvel, C. Fragoso, Faunal activity in acid soils, in: R.A. Date et al. (Eds.), Plant Soil Interactions at Low pH, Kluwer Academic Publishers, The Netherlands, 1995, pp. 201-211.

[32] A.L.C. Franco, M.L.C. Bartz, M.R. Cherubin, D. Baretta, C.E.P. Cerri, B.J. Feigl, D.H. Wall, C.A. Davies, C.C. Cerri, Loss of soil (macro)fauna due to the expansion of Brazilian sugarcane acreage, Sci. Tot. Environ. 563 (2016) 160-168.

[33] H. Eijsackers, Earthworms as colonisers: Primary colonisation of contaminated land, and sediment and soil waste deposits, Sci. Tot. Environ. 408 (2010) 1759-1769.

[34] R. Courtney, E. Feeney, A. O'Grady, An ecological assessment of rehabilitated bauxite residue, Ecol. Engin. 73 (2014) 373-379.

[35] R. Courtney, N. O'Neil, T. Harrington, J. Breen, Macro-arthropod succession in grassland growing on bauxite residue, Ecol. Engin. 36 (2010) 1666-1671.

[36] Google Maps, Map of Nob End near Bolton, Lancashire https://www.google.co.uk/maps/place/Nob+End+SSSI (accessed 02/2016). 


\section{Acknowledgements}

Phil Sharples (Ex-Bolton Council) for history of site and management practices.

Colman's of Norwich for provision of mustard powder.

Appendix A: Supplementary material

\section{Funding}

This research did not receive any specific grant from funding agencies in the public, commercial, or not-for-profit sectors. 


\section{Figure Legends}

Figure 1 Aerial View of Nob End SSSI [36] - showing the island-like nature of the site, surrounded by 2 rivers and a canal. (MAN - Managed grassland, UNMAN -unmanaged grassland, CAL - Calluna-rich area; Dashed line was position of line transect; Numbers 1 - 5 were areas were sampled for possible earthworm colonisation).

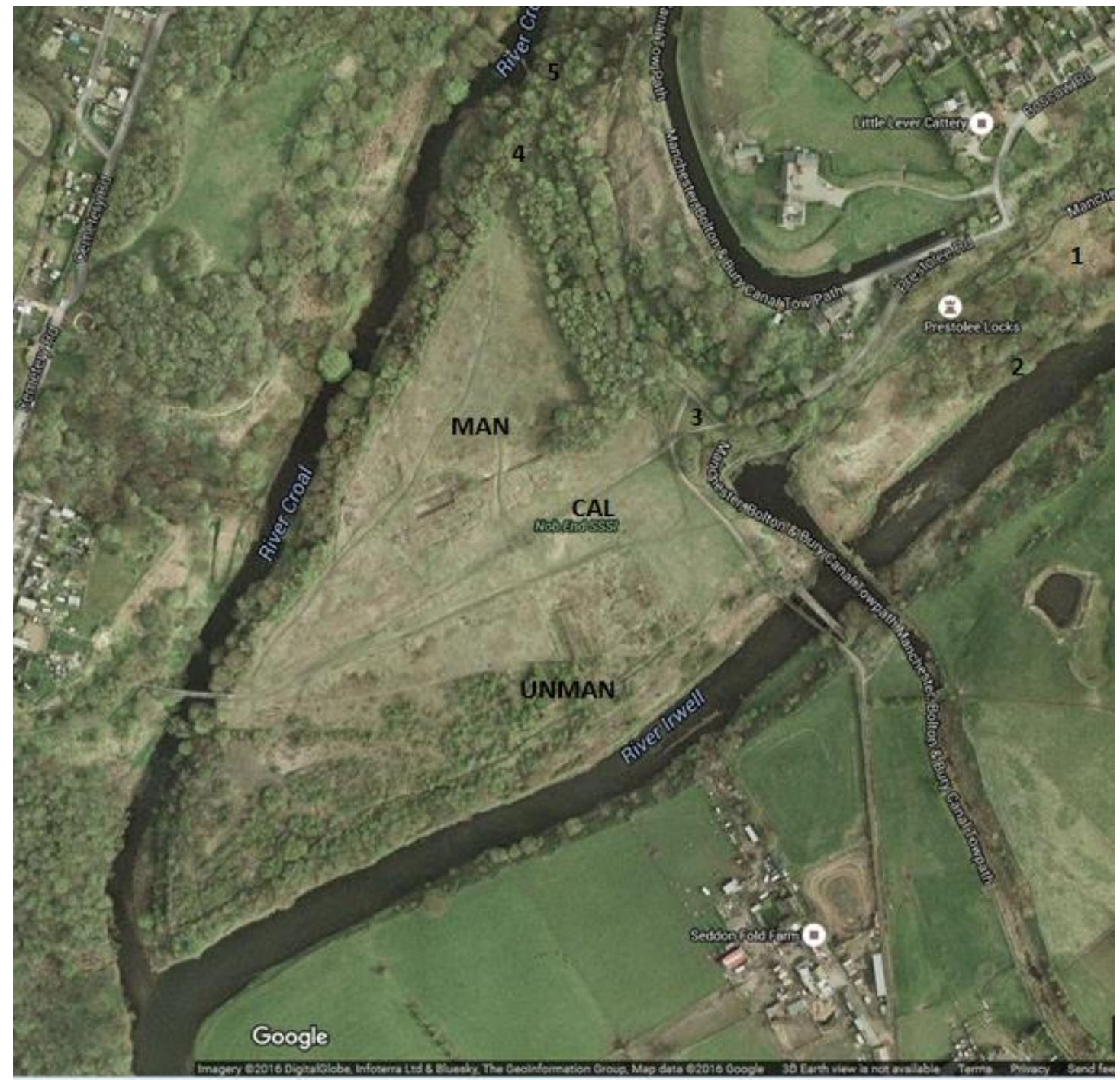


Figure 2 Densities of (a) Enchytraeids, (b) Microarthropods and (c) Diptera larvae (mean + standard error $\mathrm{m}^{-2}$ ) at 3 sites (UNMAN - unmanaged, MAN - managed, CAL - Calluna-rich) of Nob End in October 2008.

a)

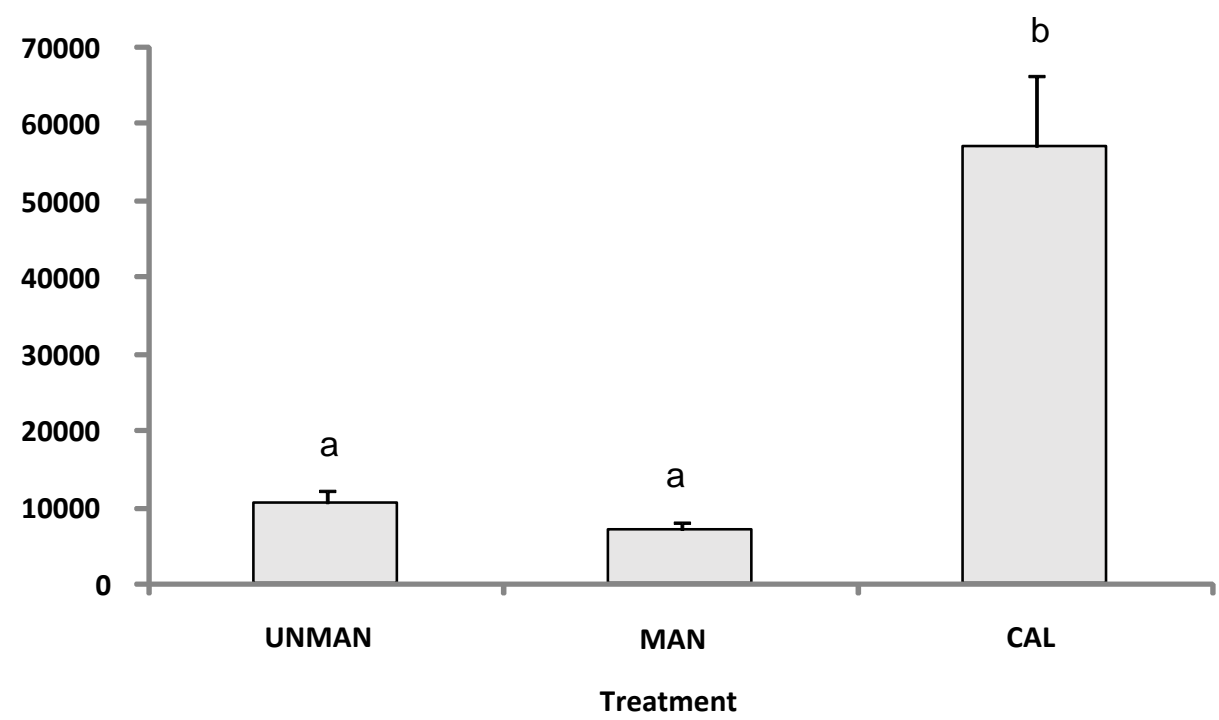

b)

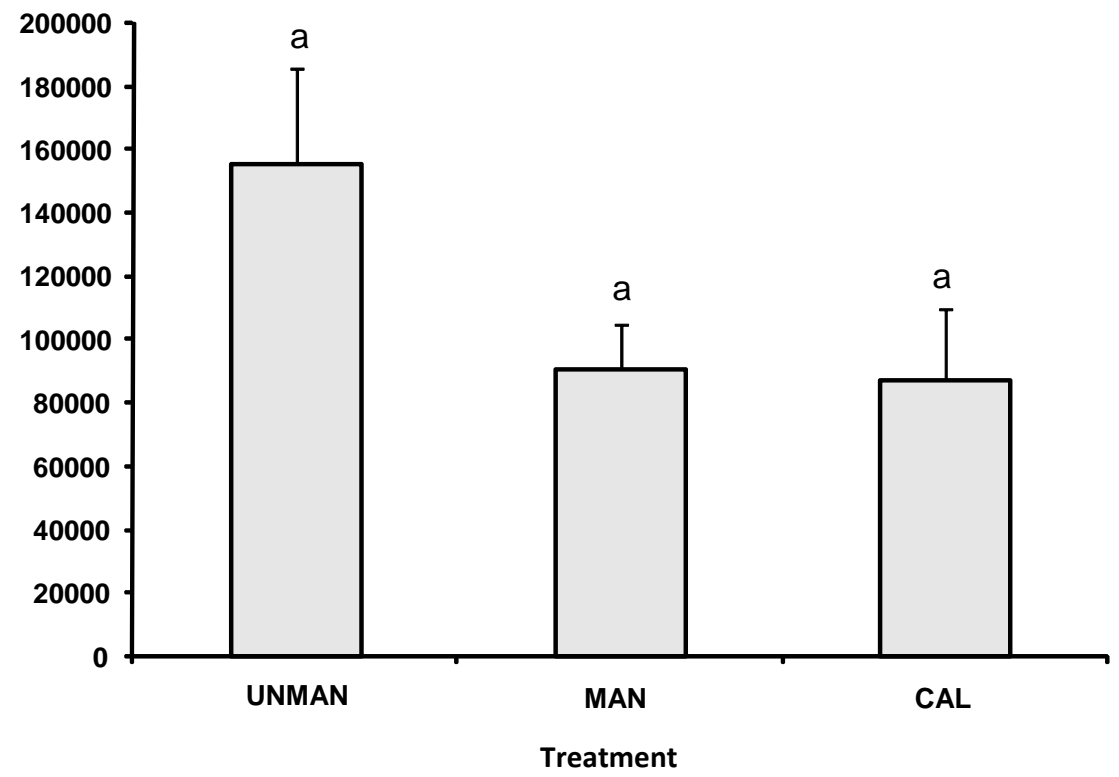


c)

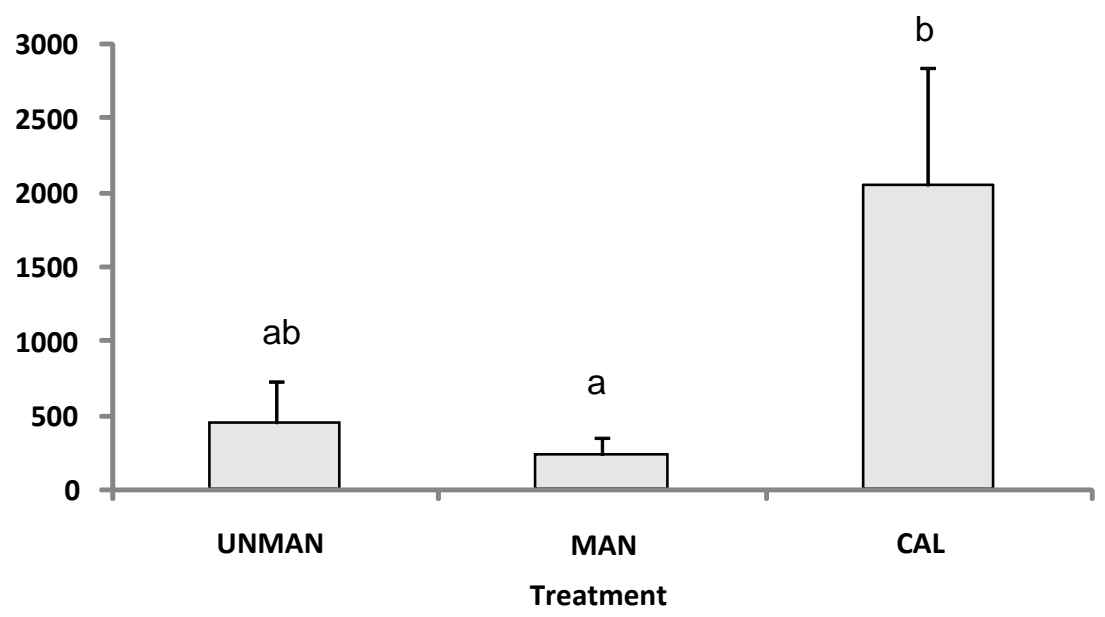


Figure 3 Means and standard errors of microarthropod diversity at 3 sites (UNMAN - white, MAN - black, CAL - grey) of Nob End in October 2008. (D - Simpson's Diversity Index; H Shannon-Wiener Index; E - Evenness).

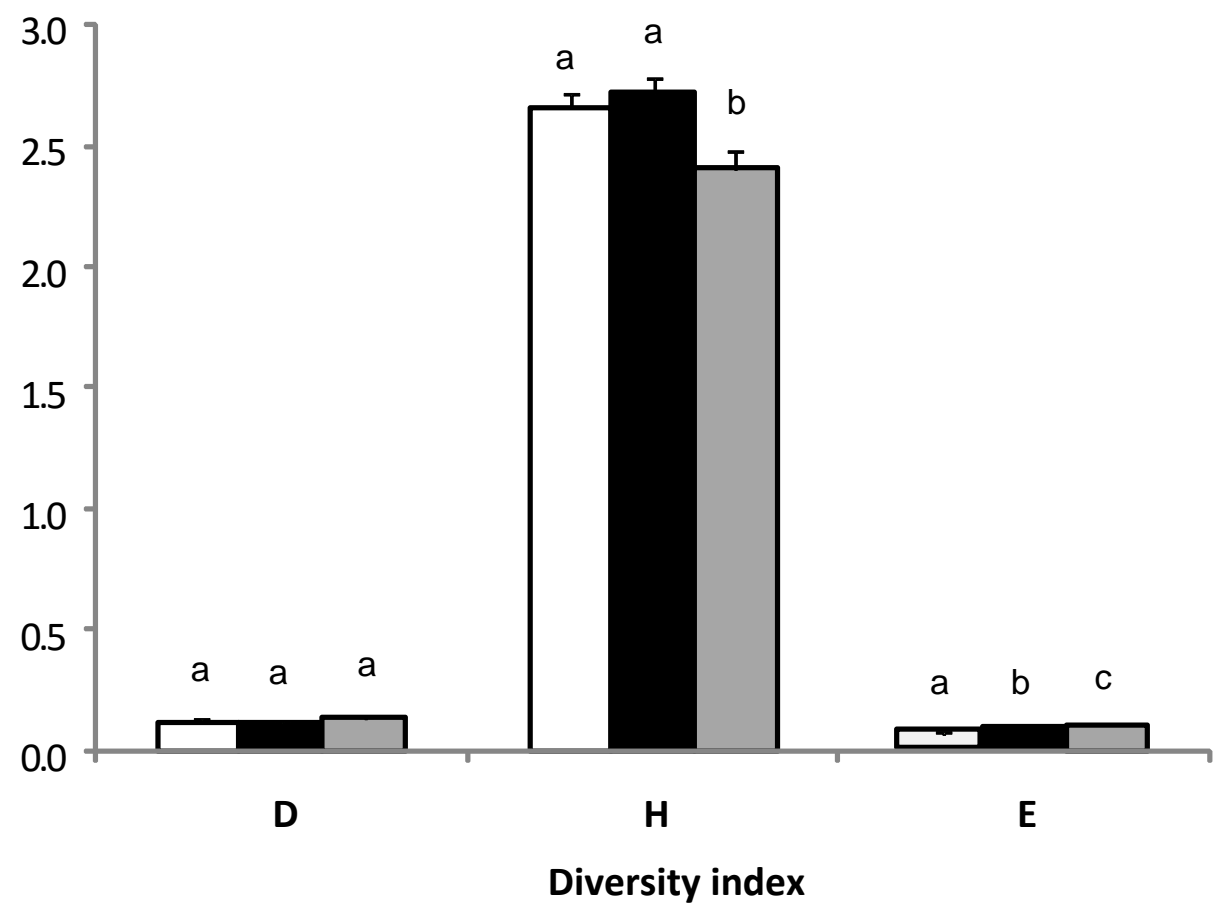


Figure 4 Line transect data from Calluna-rich grassland (CAL; $0 \mathrm{~m}$ ) to Unmanaged alkaline grassland (UNMAN; $110 \mathrm{~m}$ ) across the Nob End site (see Figure 1); (a) soil pH values and (b) earthworm community density (No. $\mathrm{m}^{-2}$ ) (September 2009).

a)

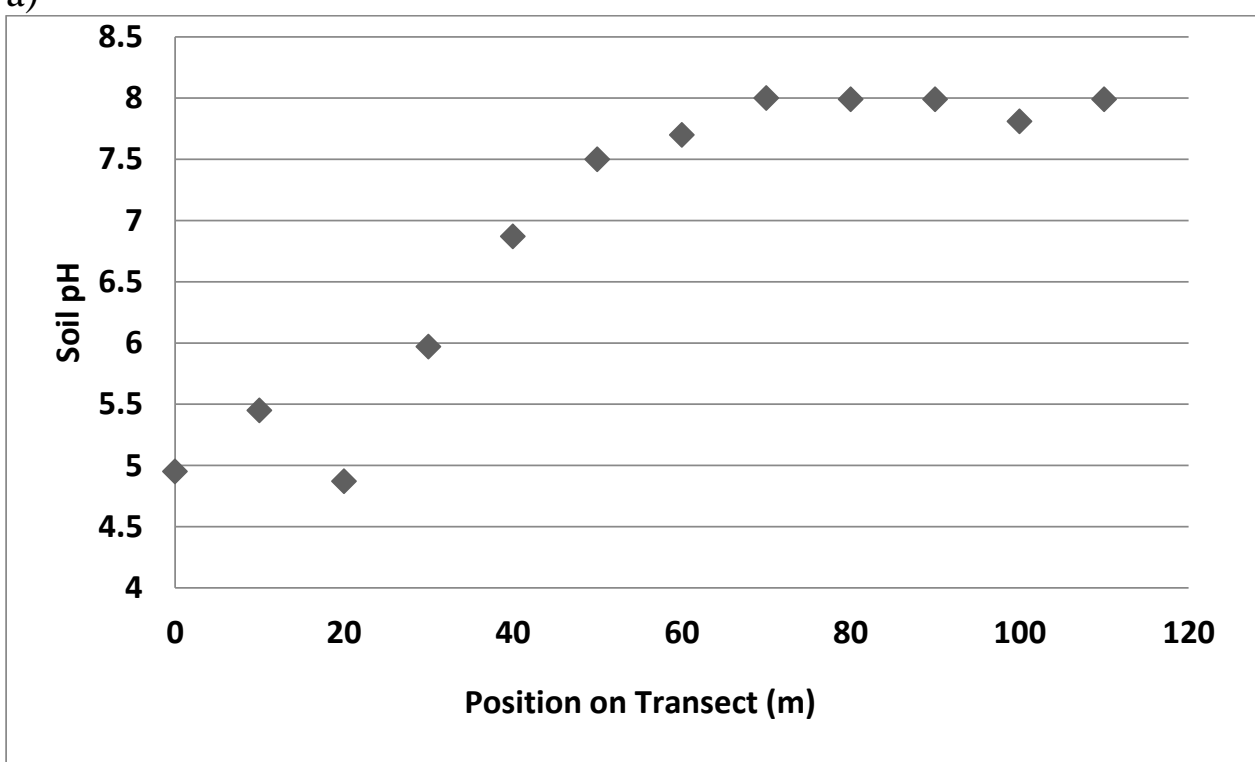

b)

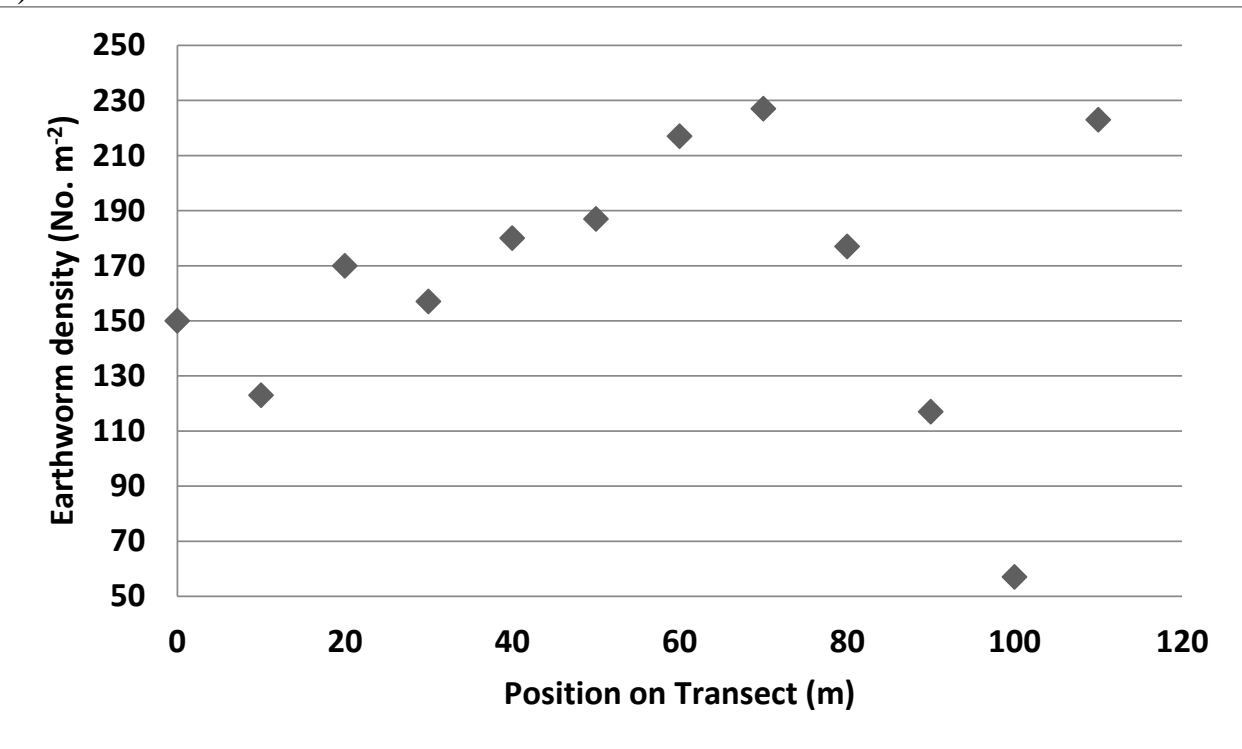


Table 1: Soil properties from three selected grassland habitats at Nob End recorded in October 2008

Grassland Habitat

Moisture Content (\%) Loss on ignition (\%) $\quad \mathrm{pH}$

Unmanaged (UNMAN)

27.1

19.2

8.0

Managed (MAN)

38.9

17.4

5.8

Calluna-rich (CAL)

38.0

20.8

4.6

Table 3: Density of micro-arthropod subphyla (number $\left.\mathrm{m}^{-2}\right)$ in selected habitat areas at Nob End sampled in October 2008 (please refer to Tab. 1 for meaning of MAN, UNMAN and CAL).

\begin{tabular}{lllll}
\hline & Chelicerata & Crustacea & Hexapoda & Myriapoda \\
& & & & \\
\hline UNMAN & $148644.79 \mathbf{a}$ & $237.76 \mathbf{a}$ & $5777.46 \mathbf{a}$ & $404.18 \mathbf{a}$ \\
& $( \pm 29999.02)$ & $( \pm 137.27)$ & $( \pm 835.01)$ & $( \pm 117.82)$ \\
& & & & \\
MAN & $80385.16 \mathbf{a b}$ & $546.84 \mathbf{a b}$ & $86678.08 \mathbf{a}$ & $784.59 \mathbf{a b}$ \\
& $( \pm 13910.70)$ & $( \pm 94.11)$ & $( \pm 13338.04)$ & $( \pm 150.58)$ \\
& & & & \\
CALL & $60128.39 \mathbf{b}$ & $0 \mathbf{b}$ & $26890.16 \mathbf{b}$ & $71.33 \mathbf{b}$ \\
& $( \pm 15956.75)$ & $( \pm 0)$ & $( \pm 6987.70)$ & $( \pm 50.75)$ \\
& & & & \\
\hline
\end{tabular}

Different letters in the same column indicate a significant difference $(p<0.05)$ 
Table 4: Density of microarthropod orders (number $\mathrm{m}^{-2}$ ) in selected habitat areas at Nob End sampled in October 2008 (please refer to Tab. 1 for meaning of MAN, UNMAN and CAL).

\begin{tabular}{lllll}
\hline & Collembola & Trombidiformes & Sarcoptiformes & Mesostigmata \\
\hline UNMAN & $3661.44 \mathbf{a}$ & $17641.46 \mathbf{a}$ & $124964.34 \mathbf{a}$ & $6015.22 \mathbf{a}$ \\
& $( \pm 606.89)$ & $( \pm 2784.84)$ & $( \pm 26749.03)$ & $( \pm 1009.99)$ \\
& & & & \\
MAN & $6538.28 \mathbf{a}$ & $18449.83 \mathbf{a}$ & $56514.50 \mathbf{b}$ & $5373.28 \mathbf{a}$ \\
& $( \pm 1191.02)$ & $( \pm 4073.45)$ & $( \pm 9868.69)$ & $( \pm 1242.11)$ \\
& & & & $3851.64 \mathbf{a}$ \\
CALL & $25558.73 \mathbf{b}$ & $25320.97 \mathbf{a}$ & $30860.68 \mathbf{b}$ & $( \pm 1629.12)$ \\
& $( \pm 6673.20)$ & $( \pm 6314.46)$ & $( \pm 8407.93)$ & \\
\hline
\end{tabular}

Different letters in the same column indicate a significant difference $(p<0.05)$ 
Table 5: Line transect data across Nob End from a Calluna-rich grassland site at $0 \mathrm{~m}$ to an unmanaged alkaline site at $110 \mathrm{~m}$.

\begin{tabular}{llllll}
\hline Distance & Soil & Density & Biomass & Earthworm & Spp No \\
$(\mathrm{m})$ & $\mathrm{pH}$ & $\left(\mathrm{no} \mathrm{m}^{-2}\right)$ & $\left(\mathrm{g} \mathrm{m}^{-2}\right)$ & species &
\end{tabular}

\begin{tabular}{llllll}
\hline 0 & 4.45 & 150 & 22 & Do, Dr, Lr & 3 \\
10 & 5.45 & 123 & 41 & Ach, Ac, Al, Do, Dr, Lc, Lr & 7 \\
20 & 4.87 & 237 & 53 & Ach, Ac, Al, Dr, Lr & 5 \\
30 & 5.97 & 143 & 49 & Ach, Ac, Al, Ar, Dr, Lc, Lt, Oc & 8 \\
40 & 6.87 & 180 & 62 & Ach, Ac, Al, Ar, Lr, Lt & 6 \\
50 & 7.49 & 187 & 58 & Ach, Ac, Al, Ar, Lr, Lt & 6 \\
60 & 7.76 & 217 & 87 & Ac, Ai, Al, Ar, Dr, Lr, Lt & 7 \\
70 & 8.00 & 227 & 80 & Ac, Al, Ar, Lr, Lt & 5 \\
80 & 7.99 & 177 & 57 & Ac, Al, Ar, Lt & 4 \\
90 & 7.99 & 117 & 56 & Ac, Al, Ar, Lc, Lt & 5 \\
100 & 7.80 & 57 & 21 & Ac, Al, Ar, Dr, Lr & 5 \\
110 & 7.99 & 223 & 83 & Ac, Al, Ar, Dr, Lc, Lt & 6 \\
\hline
\end{tabular}

[Ach - Allolobophora chlorotica; Ac - Aporrectodea caliginosa; Ai - Aporrectodea icterica; Al Aporrectodea longa; Ar - Aporrectodea rosea; Do - Dendrobaena octaedra; $\mathrm{Dr}$ - Dendrodrilus rubidus; Lc - Lumbricus castaneus; Lr - Lumbricus rubellus; Lt - Lumbricus terrestris; Oc Octolasion cyaneum] 
Table 6: Earthworm records from potential colonisation areas adjacent to Nob End

\begin{tabular}{lcccc}
\hline Area & Soil $\mathrm{pH}$ & Density $\left(\mathrm{no} \mathrm{m}^{-2}\right)$ & Biomass $\left(\mathrm{g} \mathrm{m}^{-2}\right)$ & Species \\
& & & \\
\hline A (Woodland) & 7.81 & 143 & 66 & Ac, Al, Ar, Oc \\
B (Riverside) & 7.31 & 13 & 6 & Al, Lr \\
C (Canal-side grassland) 7.40 & 330 & 102 & Ach, Ac, Al, \\
& & & & Ar, Do, Lt \\
D (Weir-side woodland) & 6.55 & 103 & 66 & Ac, Al, Ar, Lt, \\
& & & & Oc \\
\hline E (Japanese Knotweed) 4.67 & 97 & 76 & Ach, Ac, Al, \\
& & & Lc, Oc \\
\hline
\end{tabular}

[Species abbreviations as for Table 5] 
Table 2: Earthworm density (number $\mathrm{m}^{-2}$ ) and biomass (grams $\mathrm{m}^{-2}$ ) in parenthesis, from sampling at 3 sites (UNMAN - unmanaged, MAN - Managed; CAL Calluna-rich) at Nob End in October 2008.

\begin{tabular}{lllllllllllll} 
Earthworm species & Ac & Al & Ar & Oc & Lc & Lr & Lt & Spp & Totals \\
\hline UNMAN & $96(23.4)$ & $10(5.6)$ & $16(2.4)$ & $0(0)$ & $0(0)$ & $0(0)$ & $6(6.9)$ & $6(1.2)$ & $134 \mathbf{a b}(39.5 \mathbf{a})$ \\
MAN & $86(22.2)$ & $42(36.1)$ & $58(7.6)$ & $4(2.2)$ & $2(0.3)$ & $0(0)$ & $8(9.0)$ & $4(0.4)$ & $204 \mathbf{a}(77.8 \mathbf{b})$ \\
& & & & & & & & & & & & \\
CAL & $2(0.9)$ & $0(0)$ & $0(0)$ & $0(0)$ & $6(0.6)$ & $56(16.1)$ & $0(0)$ & $0(0)$ & $64 \mathbf{b}(17.6 \mathbf{c})$
\end{tabular}

[Ac - Aporrectodea caliginosa; Al - Aporrectodea longa; Ar - Aporrectodea rosea; Oc - Octolasion cyaneum; Lc - Lumbricus castaneus; Lr - Lumbricus rubellus; Lt - Lumbricus terrestris; Spp - Unidentified juveniles]. Different letters in the total columns indicate a significant difference $(\mathrm{p}<0.5)$. 
